Cakrawala Dini: Jurnal Pendidikan Anak Usia Dini | p-ISSN 2087-I317 | e-ISSN 262I-8321

Vol. 9. No.2 November 2018 | Hal 125-137

\title{
PEMEROLEHAN BAHASA PADA BAYI DAN ANAK
}

\author{
Chairunnisa $^{1}$ \\ STKIP Kusumanegara
}

\begin{abstract}
This paper explained about the language acquisition of the infant and child. The language acquisition involved the research method and language development. Some researcher conducted the research by using some methods and designs such as diary and parental report, interview, observation, and experiment. The researcher also identified the process of childrens' language acquisition and also identified the process of acquisition. In this paper also describe the speech perception development, process of language acquisition from phonology, sintaxis, and lexical. Not only explained about the process and kinds of childreens' language acquisition but also it is explained the way child give the sense of the words or related to pragmatic.
\end{abstract}

Keyword: Language Acquisition; infant; , child.

\begin{abstract}
Abstrak: Artikel ini menjelaskan tentang perolehan bahasa bayi dan anak. Akuisisi bahasa melibatkan metode penelitian dan pengembangan bahasa. Beberapa peneliti melakukan penelitian dengan menggunakan beberapa metode dan desain seperti buku harian dan laporan orang tua, wawancara, observasi, dan percobaan. Peneliti juga mengidentifikasi proses akuisisi bahasa anak-anak dan juga mengidentifikasi proses akuisisi. Dalam tulisan ini juga menggambarkan perkembangan persepsi tutur, proses perolehan bahasa dari fonologi, sintaksis, dan leksikal. Tidak hanya menjelaskan tentang proses dan jenis penguasaan bahasa anak-anak tetapi juga dijelaskan cara anak memberi arti kata-kata atau terkait dengan pragmatis.
\end{abstract}

Kata Kunci: Pemerolehan Bahasa; Anak; Bayi

\section{PENDAHULUAN}

Istilah pemerolehan dipakai untuk padanan istilah Inggris acquisition, yakni, proses penguasaan bahasa yang dilakukan oleh anak secara natural pada waktu dia belajar bahasa ibunya (native language). Istilah ini dibedakan dari pembelajaran yang merupakan padanan dari istilah Inggris learning. Dalam pengertian ini proses itu dilakukan dalam tatanan yang formal, yakni belajar di kelas dan diajar oleh seorang guru. Dengan demikian, proses dari anak yang belajar menguasai bahasa ibunya disebut dengan pemerolehan, sedangkan proses dari orang (umumnya dewasa) yang belajar di kelas adalah disebut pembelajaran.

Pemerolehan bahasa merupakan proses manusia mendapatkan kemampuan untuk menangkap, menghasilkan, dan menggunakan kata untuk pemahaman dan komunikasi. Kapasitas ini melibatkan berbagai kemampuan seperti sintaksis, fonetik, dan kosa kata yang luas. Bahasa yang diperoleh bisa berupa vokal seperti pada bahasa lisan atau manual seperti pada bahasa isyarat. Pemerolehan bahasa biasanya merujuk pada pemerolehan bahasa pertama yang mengkaji pemerolehan anak terhadap bahasa ibu mereka dan bukan pemerolehan bahasa kedua yang mengkaji pemerolehan bahasa tambahan oleh anak-anak atau orang dewasa.

Lingusitik dan psikolinguistik modern dapat menjelaskan kepada kita tentang bagaimana dan apa yang dipelajari oleh seorang anak. Mereka dapat menguasah langkah tersebut melalui kompetensi komunikasi (communicative 
competence). Tetapi ada beberapa pertanyaan yang belum terjawab yaitu Bagaimana sebenarnya anak memperoleh bahasa?; Bagaimana anak menentukan makna sebuah kata?; atau bagaimana menghasilkan stuktur ujaran yang belum pernah mereka dengar sebelumnya? Para peneliti belum setuju tentang mengapa anak belajar bahasa; apakah anak belajar bahasa karena orang dewasa mengajarkan bahasa kepada mereka? Atau hal tersebut diprogram secara genetik untuk menerima bahasa? Apakah mereka belajar grammar yang komplek karena memang tersedia? Atau Apakah mereka belajar bahasa karena mereka membutuhkan hal tersebut untuk berkomunikasi? Perkembangan psikolingusitik merupakan ilmu yang membahas tentang pemerolehan bahasa anak tersebut (Gleason \& Ratner, 1998).

Dalam pemaparan makalah ini, pertanyaan-pertanyaan yang muncul di atas akan dibahas dan setidaknya dapat memberikan gambaran tentang bagaimana proses pemerolehan bahasa pada anak.

\section{PEMBAHASAN}

\section{Proses Internalisasi Sistem Bahasa}

Pembelajaran bahasa merupakan sebuah proses internalisasi sistem. Proses ini sangat jelas dan sistematik yang ditegaskan kembali oleh Noam Chomsky dalam teori generatif transformasi bahasa. Noam Chomsky (2006), seorang linguis 'penemu' teori tatabahasa generatif transformasi bahasa, ia berkeyakinan bahwa dalam diri anak terdapat semacam "alat" yang dipergunakan sebagai sarana memperoleh bahasa. Sejak dilahirkan anak sudah memiliki pembawaan, bakat (innate capacity), yang berupa Language Acquisition Devices (LAD) untuk memperoleh bahasa secara alami. Adanya innate capacity atau LAD tersebut menurut Chomsky dapat dipergunakan untuk menerangkan apa yang terjadi di dalam diri anak yang secara ajaib dapat belajar bahasa secara cepat. Berbeda dengan teori tabularasa yang menyatakan bahwa otak bayi pada waktu dilahirkan diibaratkan seperti kertas kosong, yang nanti akan ditulis dengan pengalamanpengalaman. Skinner mengatakan bahasa terlahir dari bentuk $\mathrm{S}-\mathrm{R}$, stimulus respon. (Gleason \& Ratner, 1998). Lain lagi dengan teori Piaget mengkaji perkembangan kognitif yang mencakup bahasan tentang bahasa, yang kemudian dikenal dengan hipotesis kesemestaan kognitif.

Noam Chomsky, menyebutkan bahwa jika kita mempelajari bahasa maka pada hakikatnya kita sedang mempelajari esensi manusia, yang menjadikan keunikan manusia itu sendiri. Manusia dirancang untuk berjalan, tetapi tidak diajari agar bisa berjalan. Demikian pula dalam berbahasa, tidak seorangpun bisa diajari bahasa karena manusia diciptakan untuk berbahasa. Dalam artian bahwa pada kenyataannya manusia akan berbahasa tanpa bisa dicegah agar dia tidak memperoleh bahasa.

$$
\text { Selanjutnya, Chomsky }
$$

beranggapan bahwa pengguna bahasa mengerti struktur dari bahasanya yang membuat seseorang dapat mengkreasikan kalimat-kalimat baru yang tidak terhitung jumlahnya dan membuat seseorang mengerti kalimat-kalimat tersebut. Selama pemerolehan bahasa pertama, Chomsky menyebutkan ada dua proses yang terjadi ketika seorang anak memperoleh bahasa pertamanya. Proses yang dimaksud adalah proses kompetensi dan proses performansi. Kedua proses ini merupakan dua proses yang berlainan, kompetensi adalah pengetahuan intuitif yang dimiliki seorang individu mengenai bahasa ibunya (native languange). Intuisi linguistik ini tidak begitu saja ada, tetapi dikembangkan pada anak sejalan dengan pertumbuhannya, sedangkan performansi adalah sesuatu yang dihasilkan oleh kompetensi. Kompetensi adalah proses penguasaan tata bahasa (fonologi, morfologi, sintaksis, dan semantik) secara alamiah. Kompetensi ini dibawa oleh setiap anak sejak lahir. Meskipun dibawa 
sejak lahir, kompetensi memerlukan pembinaan sehingga anak-anak memiliki performansi dalam berbahasa. Performansi adalah kemampuan anak menggunakan bahasa untuk berkomunikasi. Performansi terdiri dari dua proses, yaitu proses pemahaman dan proses penerbitan kalimat-kalimat. Proses pemahaman melibatkan kemampuan mengamati atau mempersepsi kalimatkalimat yang didengar, sedangkan proses penerbitan melibatkan kemampuan menghasilkan kalimat-kalimat sendiri.

Kapan sebenarnya anak berbahasa? Karena berbahasa mencakup komprehensi maupun produksi, maka sebenarnya anak sudah mulai berbahasa sebelum dia dilahirkan. Melalui saluran intrauterine anak telah terekspos pada bahasa manusia waktu dia masih janin. Kata-kata dari ibunya tiap hari dia dengar dan secara biologis kata-kata itu "masuk" ke janin. Kata-kata ibunya ini rupanya tertanam pada janin anak. Itulah salah satu sebabnya mengapa di mana pun juga anak selalu lebih dekat pada ibunya daripada ayahnya. Seorang anak yang menangis akan berhenti menangisnya bila digendong oleh ibunya.

\section{Early Speech Perception.}

Pada tahap ini, periode singkat dimana setelah anak lahir, anak dapa menunjukkan melalui HASP experiment. Mereka menerima voice onset time(VOT) seperti yang dilakukan oleh orang dewasa. Pada periode ini anak mampu membedakan antara suara laki-laki dan suara perempuan, serta dapat menunjukkan bahasa yang tidak sempurna seperti potongan klausa. Dan pada akhirnya anak pada usian 9 bulan dapat mengerti tentang bunyi yang teratur pada bahasanya sebelum menghasilkan bahasa pertamanya.

Dengan memakai alat yang dinamakan High Amplitude Sucking Paradigm (HASP) anak umur di bawah 3 bulan ternyata sudah dapat membedakan VOT. Pada eksperimen ini anak diberi dot khusus lalu diperdengarkan bunyi, misalnya /ba/. Pada saat mendengar bunyi itu, jumlah denyutan naik, tapi kemudian turun. Kemudian diberikan bunyi lain /pa/ dan denyutannya naik lagi. Dari hal ini dapat disimpulkan bahwa anak telah dapat membedakan bunyi sangat awal.

\section{Linguistic Specialitation.}

Pada periode ini, anak mampu membedakan antara speech sound, kemudian mengenalinya, seperti: anatar voice and unvoice pada sound $/ \mathrm{p} / \mathrm{dan} / \mathrm{b} /$ dalam bahasa.

Bahasa dikatakan menjadi keunikan yang mencirikan manusia dan membedakannya dengan makhluk hidup lainnya. Pernyataan ini tidak berarti bahwa hanya manusia yang memiliki piranti komunikasi. Binatang disebut tidak berbahasa tapi tetap bisa berkomunikasi. Ocehan burung kakatua yang bisa menyerupai ucapan manusia; perintah 'duduk' atau 'kejar' yang dipahami anjing; kemampuan monyet untuk memahami perintah ujaran manusia; nyanyian burung yang berirama; tempo bunyi yang didengungkan lebah; suara-suara yang dikeluarkan ikan paus; semua itu adalah contoh piranti komunikasi binatang. Piranti ini tidak serta merta disebut bahasa walaupun memang menyerupai bahasa. Contoh piranti komunikasi di atas tidak menyandang sebutan bahasa karena tidak memenuhi prasyarat bahasa seperti: unsur pertukaran pesan dari pembicara pada pendengar dan sebaliknya; adanya umpan-balik dari pembicara; kebermaknaan dan pembedaan unit-unit kosakata; adanya proses transmisi kultural yang melatarbelakangi ujaran; munculnya kreatifitas dan kemampuan pemolaan unit bahasa; pengendalian maksud bicara dan peralihan giliran bicara, serta penggunaan ungkapan yang bukan bermakna literal.

Ciri-ciri di atas dicetuskan pertama kali oleh Charles Hockett (1963) yang kemudian melahirkan pro-kontra seputar pengistilahan bahasa. Linguis lain 
menyebutkan bahwa keutamaan bahasa adalah pada kebermaknaan dan fungsi komunikatifnya. Namun demikian kompleksitas berbahasa kurang menjadi titik tekannya. Field kemudian mengkategorikan ciri-ciri tersebut ke dalam kelompok-kelompok yang meliputi saluran bahasa, ciri-ciri semantis, pembelajaran, struktur, dan fungsi.(Field, 2003)

Namun demikian, semua orang sependapat bahwa dalam proses akuisisi bahasa anak juga melewati tahap-tahap tertentu untuk "belajar" bahasa karena kemampuan sensori-motor yang masih terbatas. Pola bahasa, kata-kata, pertama anak yang dapat disuarakan adalah berupa bentuk-bentuk perulangan silabik vokal dan konsonan untuk akhirnya menjadi kata-kata tunggal. Misalnya, ucapan "mama, ba-ba, pa-pa" yang pada umumnya berakhir dengan vokal dan kata-kata itu familiar yang sering didengarnya baik dari orang maupun benda atau binatang. Setelah berumur 18 bulan atau 2 tahun anak mulai mampu mempergunakan dua tiga kata sebagai "kalimat" untuk mengekspresikan maksud dan tindakan, seperti "mama maem, dada papa, dada mama". Dalam usia tiga tahun anak dapat memahami bahasa secara luar biasa. Proses internalisasi input struktur yang semakin kompleks dan kosakata yang semakin luas itu terus berlangsung sampai anak masuk sekolah, dan pada saat ini anak sudah "menguasai" bahasanya. Di sekolah anak tidak hanya belajar bagaimana mengatakan, tetapi juga belajar apa yang tidak boleh dikatakan dalam kaitannya dengan fungsi sosial bahasa(Brown, 2000)

Proses internalisasi tidak hanya terdapat pada tingkat tataran fonologi, morfologi dan gramatikal saja, akan tetapi internalisasi juga terdapat pada komponen semantic bahasa. Pengembangan bahasa tidak dapat dijadikan suatu pemikiran terkecuali pengembangan tersebut ditekankan pada hubungan struktur dari pengalaman. Setiap masyarakat memiliki pemikiran tentang kejadian, penilaian dan keistimewaan pengalaman yang telah dialami dan kematangan individu yang ia lalui dan hadapi. Bahasa dari persepektif lain merupakan sebuah representative sistem symbol yang terdapat pada keseluruhan budaya dan pengalaman social dari suatu masyarakat.

Dengan demikian, Proses pemerolehan bahasa berbeda dengan pembelajaran bahasa. Pemerolehan bahasa lebih kepada bahasa pertama atau bahasa ibu, sedangkan pembelajaran bahasa berkaitan dengan proses yang terjadi ketika seseorang mempelajari bahasa kedua dan seterusnya, karena dalam pengembangan bahasa anak, terdapat beberapa variasi tingkatan pada proses internalisasi sIstem bahasa yaitu sIstem yang pertama kali anak peroleh atau internalisasi yang menjadi dasar munculnya sIstem suara dari bahasa yaitu fonologi, kemudian pemerolehan morfologi (kosakata), sistematik, sistem semantik bahasa (Mukalel, 2003).

\section{Pemerolehan Bahasa dalam Bidang Fonologi}

Pada waktu dilahirkan, anak hanya memiliki sekitar $20 \%$ dari otak dewasanya. Hal ini berbeda dengan binatang yang sudah memiliki sekitar $70 \%$. Proporsi yang ditakdirkan kecil pada manusia ini mungkin memang dirancang agar pertumbuhan otaknya proporsional pula dengan pertumbuhan badannya. Adapun pada umur sekitar 6 minggu, anak mulai mengeluarkan bunyi-bunyi yang mirip dengan bunyi konsonan dan vocal. Bunyi-bunyi ini belum dapat dipastikan bentuknya karena memang belum terdengar dengan jelas. Proses mengeluarkan bunyi-bunyi seperti itu disebut cooing, atau dalam bahasa Indonesia disebut dekutan.( Dardjowidjojo, 2000)

Beranjak usia 6 bulan, anak mulai melakukan babbling yang diterjemahkan dalam bahasa Indonesia menjadi celotehan, yakni mencampur konsonan 
dengan vokal. (Dardjowidjojo, 2000) Celotehan dimulai dengan konsonan dan diikuti oleh sebuah vokal. Konsonan yang keluar pertama adalah konsonan bilabial hambat dan bilabial nasal. Vokalnya adalah /a/. Jadi, strukturnya adalah CV (Consonan-Vocal). Ciri lain dari celotehan adalah bahwa $\mathrm{CV}$ ini kemudian diulang sehingga munculah struktur, seperti berikut:

(1) C1 V1 C1 V1 C1 V1 ...papapa mamama bababa ...

Pada anak di Barat, kata sudah mulai muncul pada umur sekitar 1 tahun. Adapun pada anak Indonesia, contohnya pada Echa, munculnya kata pertama agak terlambat, yakni mendekati usia 1 tahun 6 bulan. Berkaitan dengan hal ini, argumentasi yang ada adalah bahwa anak Indonesia memerlukan waktu yang lebih lama untuk menentukan suku mana yang akan diambil sebagai wakil dari kata itu. Pada bahasa Inggris, kebanyakan katanya adalah monosilabik, sedangkan pada bahasa Indonesia, kebanyakan katanya adalah polisilabik, di mana anak harus menganalisis katanya terlebih dahulu baru kemudian anak menentukan suku mana yang akan diambil. Misalnya, dari kata sepeda, suku kata yang diambil adalah se, pe, dan $d a$.

Berdasarkan perkembangan bahasa pada Echa, dan tidak mustahil juga pada anak Indonesia yang lain, yang diambil adalah suku terakhir. (Dardjowidjojo, 2000) Hal ini terjadi karena dilatarbelakangi bahwa anak cenderung memperhatikan ahir dari suatu bentuk kata. Adapun perkembangan konsonan pada akhir kata terjadi sampai anak berusia sekitar 2 tahun. Banyak konsonan pada akhir kata yang tidak diucapkan oleh anak, seperti kata mobil yang akan diujarkan sebagai /Bi/. Selanjutnya, sampai usia 3 tahun, anak belum dapat mengucapkan gugus konsonan sehingga kata (Eyang) Putri akan disapanya dengan Eyang /ti/.

Pemunculan bunyi mengikuti urutan, terjadi secara universal pada anak di Barat dan anak di Indonesia, termasuk yang terjadi dalam pemerolehan bahasa pada Echa. Anak-anak mulai menguasai bunyi konsonan bilabial dengan vokal /a/, kemudian alveolar dan velar. Contohnya, hingga usia 2 tahun, Echa memanggil kakeknya, Eyang, /tatYN/, bukan Eyang /kakYN/. Sekitar usia 2 tahun 6 bulan, kata jam masih diucapkan sebagai /tam/ atau /dam/.

Berkaitan dengan pemerolehan bahasa dalam bidang fonologi, satu hal yang harus dipahami oleh para pengajar bahasa dan juga orang tua adalah bahwa patokan tahun ini sangat relatif. Ukuran tidak boleh tahun kalender, tetapi harus neurobiologist, artinya tahap perkembangan neurobiology mana seorang anak dapat mengucapkan bunyibunyi tertentu. Adapun hal tersebut dibuktikan oleh Dhira, adik Echa, yang telah dapat mengucapkan bunyi $/ \mathrm{r} /$ pada usia 3 tahun. (Dardjowidjojo, 2000) Adanya fakta tersebut dapat meramalkan bahwa Dhira telah menguasai bunyi hambat, bunyi frikatif, dan bunyi afrikat $/ \mathrm{t} \Sigma /$ dan /dZ/. Melalui fakta tersebut dapat dibuktikan bahwa prediksi tersebut benar. Jadi, yang universal itu bukan tahunnya, tetapi urutan pemunculan bunyi-bunyi itu.

Jadi, tidak mustahil akan ada anak Indonesia yang sudah dapat mengucakan /dZ/ pada usia 2 tahun 6 bulan, tetapi jika hal ini terjadi pasti anak terebut juga sudah dapat mengucapkan /k/ dan /g/.

\section{Pemerolehan Bahasa dalam Bidang Sintaksis}

Dalam bidang sintaksis, anak memulai berbahasa dengan mengucapkan satu kata atau bagian kata. Adapun bagi anak, sebuah kata dianggap sebagai kalimat penuh, tetapi karena dia belum dapat mengatakan lebih dari satu kata, dia hanya mengambil satu kara dari seluruh kalimat itu. Berkaitan dengan perihal tersebut, Dardjowidjojo memberikan contoh, seandainya ada seorang anak bernama Dodi dan yang ingin dia sampaikan adalah Dodi mau bubuk, dia akan memilih di (untuk Dodi), mau (untuk 
mau), ataukah buk (untuk bubuk)? Bagi orang dewasa seperti kita, kita pasti akan menerka bahwa dia akan memilih buk. Namun, pertanyaannya, mengapa demikian?

Dalam pola pikir yang masih sederhana pun tampaknya anak sudah mempunyai pengetahuan tentang informasi lama versus informasi baru. Kalimat diucapkan untuk memberikan informasi baru kepada pendengarnya. Dari tiga kata pada kalimat Dodi mau bubuk, yang baru adaah kata bubuk. Karena itulah anak memilih buk, dan bukan $d i$, atau mau. Dengan singkat dapat dikatakan bahwa dalam ujaran yang dinamakan Ujaran Satu kata, USK, (one word utterance) anak tidak sembarangan saja memilih kata itu, tetapi dia akan memilih kata yang memberikan informasi baru.

Dari segi sintaksisnya, USK sangat sederhana karena memang hanya terdiri dari satu kata saja, bahkan untuk bahasa seperti bahasa Indonesia hanya sebagian saja dari kata itu. Namun, dari segi semantiknya, USK adalah kompleks karena satu kata ini bisa memiliki lebih dari satu makna. Misalnya, anak yang mengatakan /bi/ untuk mobil bisa bermaksud mengatakan:

(2) a. Ma, itu mobil.

b. Ma, ayo kita ke mobil.

c. Aku mau ke mobil.

d. Aku minta (mainan) mobil.

f. Aku nggak mau mobil.

g. Papa ada di mobil, dsb.

Ujaran satu kata yang mempunyai berbagai makna ini dinamakan ujaran holofrastik (holophrastic). (Dardjowidjojo, 2000). Di samping ciriciri yang telah dijelaskan, USK juga mempunya ciri-ciri yang lain. Pada awalnya, USK hanya terdiri dari CV saja. Bila kata itu CVC maka $\mathrm{C}$ yang kedua dilesapkan. Kata ball, misalnya terwujud sebagai /bo/ saja. Begitu juga kata mobil akan disingkat menjadi /bi/. Pada perkembangannya, konsonan akhir ini mulai muncul. Pada usia 2 tahun, contohnya, Echa menamakan ikan sebagai $/ \tan /$, perisis sama dengan kata untuk bukan.

Pada awal USK juga tidak ada gugus konsonan. Semua gugus yang ada di awal atau akhir kalimat disederhanakan menjadi satu konsonan saja. Seperti kata play dan cold masing-masing akan diucapkan sebagai /pe/ dan /kod/. Kata Indonesia putri (untuk Eyang Putri) diucapkan Echa mula-mula sebagai Eyang $/ \mathrm{ti} /$.

Ciri lain dari USK adalah bahwa kata-kata yang dipakai hanyalaha katakata dari kategori sintaktik utama (content words), yakni nomina, verba, adjektiva, dan mungkin juga adverbial. Tidak ada kata fungsi, seperti from, to, dari, atau ke. Di samping itu, kata-katanya selalu dari kategori sini dan kini. Tidak ada yang merujuk kepada yang tidak ada di sekitar atau pun ke masa lalu dan masa depan. Anak juga dapat menyatakan negasi no atau nggak, pengulangan more atau lagi, dan habisnya sesuatu gone atau abis.

Sekitar usia dua tahun, anak mulai mengeluarkan Ujaran Dua Kata, UDK (Two Word Utterance). Anak mulai dengan dua kata yang diselingi jeda sehingga seolah-olah dua kata itu terpisah. Untuk menyatakan bahwa lampunya telah menyala, Echa, misalnya, bukan mengatakan /lampunala/ "Lampu nyala" tapi /lampu // nala/ "Lampu. Nyala" dengan jeda di antara lampu dan nyala. Jeda ini makin lama makin pendek sehingga menjadi ujaran yang normal. Adanya dua kata dalam UDK maka orang dewasa lebih bisa menerka apa yang dimaksud oleh anak karena cakupan makna menjadi lebih terbatas. Jadi, berbeda dengan USK, UDK sintaksisnya lebih kompleks karena adanya dua kata sehingga semantiknya makin lebih jelas. (Dardjowidjojo, 2000)

Adapun ciri lain dari UDK adalah bahwa kedua kata ini adalah kata-kata dari kategori utama: nomina, verba, adjektiva, atau bahkan adverbia. Belum ada kata fungsi, seperti di, yang, dan, dsb. Karena 
Barbara, mendapati dalam penelitiannya bahwa urutan dua kata yang dipakai anak ternyata mengikuti aturan tertentu. Katakata tertentu selalu berada pada tempat tertentu pula dan ada kata-kata yang tidak pernah muncul sendirian. Ketiga anak yang dia selidiki tampaknya membagi kata-kata mereka menjadi dua kelompok: (a) kata-kata yang sering muncul, yang tidak pernah sendirian, dan muncul pada posisi tertentu, dan (b) kata-kata yang jumlahnya lebih besar, yang munculnya tidak sesering seperti yang ada pada (a) posisinya juga di mana saja, dan bisa muncul sendirian. Kata-kata pada (a) dinamakan pivot karena ujaran anak berkisar pada kata-kata ini, dan pada (b) dinamakan open, terbuka.

Subjek penelitian Braine selalu memakai want, get, there, dan it sebagai kata-kata pivot. Untuk kategori terbuka banyak kaya yang dipakai seperti baby, car, ball, doll, bunny, dan horsie. Adapun tata bahasa yang dikenal dengan nama Pivot Grammar, dapat terlihat pada Tabel Pivot Grammar di bawah ini:

\begin{tabular}{|l|l|}
\hline \multicolumn{1}{|c|}{ Pivot 1 } & \multicolumn{1}{c|}{ Open } \\
\hline Want & Baby \\
\hline Get & Ball \\
\hline There & Book \\
\hline It & Daddy \\
\hline
\end{tabular}

\begin{tabular}{|l|l|}
\hline \multicolumn{1}{|c|}{ Open } & Pivot 2 \\
\cline { 1 - 1 } Bunny & Do \\
\cline { 1 - 1 } Daddy & \\
\hline
\end{tabular}

$$
\begin{aligned}
& \text { Want baby } \\
& \text { Want ball } \\
& \text { Want book } \\
& \text { Want Daddy } \\
& \text { Bunny do } \\
& \text { Daddy do } \\
& \text { Mommy do } \\
& \text { Johny do }
\end{aligned}
$$$$
\text { (6) Bunny do }
$$

Sampai dengan akhir tahun 1960an Pivot Grammar mendapat sambutan yang positif. Akan tetapi, lama-kelamaan ditemukan contoh-contoh bahasa anak yang menyimpang dari tatabahasa seperti ini. Kalimat anak seperti Mummy sock,
Daddy car, dan Kitty ball yang masingmasing kalimatnya terdiri dari dua kata terbuka ternyata banyak terdapat dalam bahasa anak. Akan tetapi, Braine menyanggah balik sanggahan tersebut dengan mengatakan bentuk-bentuk seperti ini muncul sesudah tahap Pivot Grammar. (Dardjowidjojo, 2000, hlm 252.)

Pada bahasa-bahasa seperti bahasa Indonesia, di mana bentuk pasif sangat dominan, anak sering mendapat masukan yang berupa kalimat pasif dan karenanya membentuk pula pola kalimat pasif jauh lebih awal daripada anak Inggris. Anak Inggris rata-rata baru mendapat kalimat pasif pada umur 4 tahun, sedangkan anak Ibrani bisa sampai umur 8 tahun. Sebaliknya, Echa telah memakai bentuk pasif sewal umur 1 tahun 9 bulan. (Dardjowidjojo, 2000, hlm 253)

Berkaitan dengan pola universal bahasa, Brown dalam Dardjowidjojo menjelaskan bahwa anak mungikuti pola universal juga tampak pada aspek-aspek gramatikal lain, misalnya Brown menemukan ada pemerolehan 14 morfem bahasa Inggris mengikuti urutan tertentu, antara lain: (Dardjowidjojo, 2000, hlm 253-254)

1. Bentuk progresif : -ing

2. Preposisi : in

3. Preposisi : on

4. Bentuk jamak : $-s$

5. Kala lalu tak teratur : went

6. Bentuk posesif : $-S$

7. Bentuk kopula utuh be: are, was

8. Artikel : $a$, the

9. Kala lalu teratur : -ed

10. Orang ketiga tunggal $:-s$

11. Orang ketiga tak teratur : has, does

12. Kata bantu utuh be: is, were

13. Kopula disingkat be: 's, 're

14. Kata bantu disingkat be : 's. 're 
Melalui daftar di atas, terdapat beberapa hal yang perlu diperhatikan. Bentuk

-ing menempati urutan pertama karena bentuknya ajeg dan maknanya pun juga tidak pernah berubah. Dari bentuk $-S$, tampak urutannya adalah jamak (4), posesif (6), dan orang ketiga tunggal (10). Ada yang menerangkan bahwa urutan seperti ini adalah karena $-s$ pada jamak melekat pada kata, $-s$ pada posesif melekat pada frasa, dan $-S$ pada orang ketiga tunggal melekat pada klausa.

Pemerolehan kata fungsi before dan after juga dikatakan mengikuti urutan universal. Bila ada dua peristiwa A dan B, anak sampai umur 5 tahun selalu menempatkan kedua peristiwa itu sesuai dengan urutan kejadiannya. Jadi, bila peristiwa A adalah "John came" dan peristiwa B yang muncul kemudia adalah "Robert lef" maka anak akan mengurutkannya sebagai AB. Inilah yang menyebabkan mengapa kata fungsi before dikuasai lebih awal daripada after. Anak akan menguasai kalimat seperti (7) lebih dahulu daripada kalimat (8), meskipun makna kedua kalimat itu sama.

(7) John came before Robert left.

(8) Robert left after John came.

Bahkan sering pula terjadi salah pengertian mengenai makna kalimat (8) anak mengira Robert oergi barulah kemudian John datang.

Berkaitan dengan hal tersebut, pada Echa perihal tersebut tidak ditemukan. Pada usia 4 tahun 5 bulan, Echa telah dapat membedakan sebelum dari sesudah dengan baik, seperti pada contoh-contoh di bawah ini:

(9) EK : Echa tadi nyuci sebelum masak apa sesudah masak?

EC : Sesudah masak.

EK : Sesudah masak.

Terus, masaknya sebelum

nyuci apa sesudah nyuci?

EC : Sebelum nyuci.

Urutan pemerolehan juga tampak pada pemerolehan kalimat interogatif.
Kalimat interogatif ya/tidak dikuasai lebih awal daripada kalimat interogatif apa/mana. Pada urutan kedua ini juga ada urutannya, yakni, kalimat interogatif yang menanyakan apa atau siapa dikuasai lebih awal daripada yang menanyakan mengapa dan bagaimana. Alasannya mungkin sekali adalah bahwa apa dan siapa merujuk ke benda konkrit sedangkan mengapa dan bagaimana lebih abstrak dan memerlukan daya kognisi yang lebih matang.

Untuk kalimat negatif ada pula urutan yang diikuti oleh anak. Untuk bahasa Inggris, anak mulai dengan menempatkan kata no di paling awal ujaran. Kemudian, kata negatif ini dipindahkan ke tengah kalimat, persis di muka verba. Baru setelah itu dilekatkan dengan kata bantu, seperti can atau do. Perhatikan contoh-contoh berikut.

(10) No eat; no drink; no bath.

(11) Daddy no eat; Johny no drink; Teddy no come.

(12) Daddy can't eat; Mommy don't sit here.

Melalui contoh-contoh di atas, dapat terlihat bahwa antara subjek dengan predikat masih belum serasi seperti pada pemakaian don't untuk subjek Mommy (12). Selain itu, kadang-kadang anak juga memakai negatif ganda, seperti pada kalimat (13).

(13) Johny don't like nobody.

\section{Pemerolehan Bahasa pada Bidang Leksikon}

Sebelum anak dapat mengucapkan kata, dia memakai cara lain untuk berkomunikasi, antara lain memakai tangis dan gesture (gesture, gerakan tangan, kaki, mata, mulut). Pada mulanya kita kesukaran memberi makna untuk tangis yang kita dengar, tetapi lamakelamaan kita tahu pula akan adanya tangis-sakit, tangis-lapar, dan tangisbasah. Pada awal hidupnya anak memakai pula gesture, seperti senyum dan juluran tangan untuk meminta sesuatu. Menurut 
Gleason dalam Dardjowidjojo, cara-cara seperti ini anak sebenarnya memakai "kalimat" yang protodeklaratif dan protoimperatif. (Dardjowidjojo, 2000, hlm 258)

Pada anak Barat, mereka umumnya mulai memakai kata pada umur 1 tahun. Sekitar umur 1 tahun 7 bulan, anak telah memperoleh 50 kata dan mulai umur sekita 1 tahun 8 bulan, anak makin cepat pemerolehan katanya. Pada usia 2 tahun, anak diperkirakan telah menguasai 200-300 kata. Bila berkaca pada kasus Echa yang dijadikan patokan, anak Indonesia mulai memakai bentuk yang dapat dinamakan kata agak belakangan. Echa baru mengeluarkan bunyi yang dapat dikenal sebagai kata sekitar umur 1 tahun 5 bulan. Penentuan ini berlandaskan pada pandangan Dromi dalam Dardjowidjojo yang menjelaskan bahwa untuk suatu bentuk dapat dianggap telah dikuasai anak, maka bentuk itu harus memiliki (a) kemiripan fonetik dengan bentuk kata orang dewasa, dan (b) korelasi yang ajeg antara bentuk dengan referen atau maknanya. Jadi, bunyi /tan/, misalnya, dapat dianggap telah dikuasai oleh Echa untuk merujuk pada ikan karena bentuknya mirip dan dia selalu memakai bentuk ini bila merujuk pada benda tersebut. (Dardjowidjojo, 2000, hlm 258)

\section{Macam Kata yang Dikuasai}

Macam kata yang dikuasai anak mengikuti prinsip sini dan kini. Dengan demikian kata-kata apa yang akan diperoleh anak pada awal ujarannya ditentukan oleh lingkungannya. Pada anak orang terdidik yang tinggal di kota dan cukup mampu untuk membelikan bermacam-macam mainan, buku gambar, dan di rumahnya juga terdapat alat-alat elektronik, orangtuanya juga mempunyai waktu untuk bergaul banyak dengan anaknya, maka anak akan memperoleh kata-kata nomina seperti bola, anjing, kucing, beruang, radio, ikan, payung, sepatu, dan sebagainya.
Dari macam kata yang ada, yakni kata utama dan kata fungsi, anak menguasai kata utama lebih dahulu. Hal ini dikarenakan kata utama ada paling tidak tiga, yakni nomina, verba, dan adjektiva, maka pertanyaan yang muncul adalah "mana dari tiga ini yang muncul lebih dahulu". Berkaitan dengan hal ini, Dardjowidjojo menjelaskan bahwa Echa secara konsisten menguasai nomina lebih banyak daripada verba. Selama lima tahun nomina menduduki posisi yang paling atas (rata-rata 49\%) dan verba menduduki urutan kedua (rata-rata 29\%). Sementara itu, adjektiva pada urutan ketiga (13\%) dan kata fungsi menduduki urutan keempat (10\%).(Dardjowidjojo, 2000, hlm 259)

\section{Cara Anak Menentukan Makna}

Cara anak menentukan makna suatu kata bukanlah hal yang mudah. Dari masukan yang ada, anak harus menganalisis segala macam fiturnya sehingga makna yang diperolehnya itu akhirnya sama dengan makna yang dipakai oleh orang dewasa. Dalam hal penentuan makna suatu kata, anak mengikuti prinsip-prinsip universal salah satu diantaranya adalah dinamakan overextension yang diterjemahkan menjadi 'penggelembungan makna'. (Dardjowidjojo, 2000, hlm 260) Anak cenderung untuk mengambil salah satu fitur dari konsep itu, lalu menerapkannya pada konsep lain yang memiliki fitur tersebut. Contoh yang sering dipakai adalah konsep tentang bulan - moon. Pada waktu anak diperkenalkan dengan kata bulan, dia mengambil fitur bentuk fisiknya, yakni bulan itu bundar. Fitur ini kemudian diterapkan pada segala macam benda yang bundar seperti kue ulang tahun, jam dinding, piring, dan huruf o. Tiap kali terapannya itu ditolak, dia merevisi "definisi" dia tentang bulan sampai akhirnya dia memperoleh makna yang sebenarnya.

Berkaitan dengan 'penggelembungan makna', Eve Clark 
dalam Clark dan Clark pada Dardjowidjojo menjelaskan bahwa penggelembungan makna dapat dibagi berdasarkan bentuk, ukuran, gerakan, bunyi, dan tekstur, yang dapat dicontohkan dalam tabel berikut. (Dardjowidjojo, 2000, hlm 261)

\begin{tabular}{|c|c|c|}
\hline Word & $\begin{array}{c}\text { First } \\
\text { Referent }\end{array}$ & $\begin{array}{c}\text { Domain of } \\
\text { Application }\end{array}$ \\
\hline Sch & $\begin{array}{l}\text { Sound of } \\
\text { train }\end{array}$ & All moving machines \\
\hline Ass & $\begin{array}{l}\text { Toy got } \\
\text { with rough } \\
\text { hide on } \\
\text { wheels }\end{array}$ & $\begin{array}{l}\text { A few things that move } \\
\text { (e.g animals, sister, } \\
\text { wagon); all things that } \\
\text { move; all things with a } \\
\text { rough surface. }\end{array}$ \\
\hline Fly & Fly & $\begin{array}{l}\text { Specks of dirt, dust, all } \\
\text { small insects, child's } \\
\text { own toes, crumbs of } \\
\text { bread, a toad. }\end{array}$ \\
\hline Em & Worm & $\begin{array}{l}\text { Flies, ants, all small } \\
\text { insects, heads of } \\
\text { timothy grass. }\end{array}$ \\
\hline Bebe & Baby & $\begin{array}{l}\text { Other babies, small } \\
\text { statutes, figures is small } \\
\text { picture and prints. }\end{array}$ \\
\hline Fafer & $\begin{array}{l}\text { Sound of } \\
\text { train }\end{array}$ & $\begin{array}{l}\text { Steaming coffe pot, any } \\
\text { thing that hisses or } \\
\text { makes a noise. }\end{array}$ \\
\hline Sizo & Scissors & All metal objects \\
\hline $\begin{array}{l}\text { Bow- } \\
\text { wow }\end{array}$ & Dog & $\begin{array}{l}\text { Toy dog, fur piece with } \\
\text { animal head, other fur } \\
\text { pieces. }\end{array}$ \\
\hline $\begin{array}{l}\text { Wau- } \\
\text { wau }\end{array}$ & Dog & $\begin{array}{l}\text { All animal, toy dog, soft } \\
\text { house slippers, picture } \\
\text { of an old man dressed in } \\
\text { furs. }\end{array}$ \\
\hline $\mathrm{Va}$ & $\begin{array}{l}\text { White } \\
\text { plush dog }\end{array}$ & $\begin{array}{l}\text { Muffer, cat, father's fur } \\
\text { coat. }\end{array}$ \\
\hline
\end{tabular}

Di samping overextension atau penggelembungan ini, anak juga memakai underextension yang telah diterjemahkan menjadi penciutan makna. Seperti terlihat dari istilahnya, penciutan makna membatasi makna hanya pada referen yang telah dirujuk sebelumnya. Misalnya, konsep mengenai bebek diperkenalkan pada waktu anak melihat bebek di kolam, maka gambar bebek yang ada di buku beberapa hari kemudian bukanlah bebek. Bebek harus hidup, dan berada di kolam.

\section{Cara Anak Menguasai Makna Kata/semantik}

Anak tidak menguasai makna kata secara sembarangan. Terdapat strategi- strategi tertentu yang diikuti. Adapun strategi-strategi tersebut dapat diintisarikan berdasarkan penjelasan Golinkoff dalam Gleason dan Ratner pada Dardjowidjojo. (2000). Misalnya, anak memakai strategi referensi dengan menganggap bahwa kata pastilah merujuk pada benda, perbuatan, proses, atau atribut. Dengan strategi ini anak yang baru mendengar suatu kata baru akan menempelkan makna kata itu pada salah satu dari referensi di atas. Bila kata itu cabe, dia akan melekatkan makna kata itu pada benda yang dirujuk dengan nama itu. Bila kata baru itu adalah ngumpet, dia akan memaknakan kata itu dengan perbuatan penyembunyian diri.

Adapun strategi lain adalah strategi cakupan objek (object scope). Pada strategi ini kata yang merujuk pada suatu objek merujuk pada objek itu secara keseluruhan, tidak hanya sebagian dari objek itu saja. Jadi, kalau anak diperkenalkan kepada objek seperti sepeda maka keseluruhan dari sepeda itu yang akhirnya dikuasainya, bukan hanya ban atau sadelnya saja. Pada awal pemerolehan bisa terjadi bahwa anak hanya mengambil salah satu fiturnya saja, tetapi akhirnya terbentuk pengertian bahwa yang dinamakan sepeda adalah keseluruhan dari objek itu.

Strategi ketiga adalah strategi peluasan (extendability). Strategi ini mengasumsikan bahwa kata tidak hanya merujuk pada objek aslinya saja, tetapi juga pada objek-objek lain dalam kelompok yang sama itu, Misalnya, anak diperkenalkan dengan objek yang bernama kucing, yang kebetulan bulunya hitam, dia akan tahu bahwa kucing lain yang bulunya putih juga dinamakan kucing.

Strategi keempat adalah cakupan kategorial (categorical scope). Strategi ini menyatakan bahwa kata dapat diperluas pemakaiannya untuk objek-objek yang termasuk dalam kategori dasar yang sama. Setelah diperkenalkan dengan perkutut sebagai burung, dan kemudian anak 
melihat beo, maka anak akan tahu bahwa beo juga termasuk dalam kategori dasar yang sama dengan perkutut, yakni burung. Maka ia akan merujuk beo sebagai burung pula.

Strategi kelima adalah strategi "nama-baru - kategori tak bernama" (novel name-nameless category). Anak yang mendengar kata dan setelah dicari dalam leksikon mental dia ternyata kata ini tidak ada rujukannya, maka kata ini akan dianggap kata baru, dan maknanya ditempelkannya pada objek, perbuatan, atau atribut yang dirujuk oleh kata itu.

Strategi keenam adalah strategi konvensionalitas (convensionality). Anak berasumsi bahwa pembicara memakai kata-kata yang tidak terlalu umum, tetapi juga tidak terlalu khusus. Kemungkinannya adalah sangat kecil untuk orang dewasa memperkenalkannya kata binatang atau makhluk untuk merujuk seekor perkutut.

Strategi-strategi yang sifatnya universal ini membantu anak dalam menguasai makna kata. Dalam penguasaan makna kata, anak menghadapi banyak kendala karena kata memiliki derajat kesukaran yang berbedabeda. Pada umumnya, kata-kata yang konkrit lebih mudah daripada yang abstrak dan karenanya lebih mudah serta lebih cepat diperoleh.

\section{Pemerolehan Bahasa dalam Bidang Pragmatik}

Pragmatik bukan merupakan komponen keempat pada bahasa, tetapi memberikan perspektif yang berbeda mengenai bahasa. Kalimat (21-23) berikut menyampaikan maksud yang sama, tetapi dengan nuansa yang berbeda.

(21) Kamu mau pergi ke mana?

(22) Saudara mau pergi ke mana?

(23) Bapak mau pergi ke mana?

Kalimat (21) dipakai oleh orangtua kepada anak, atasan kepada bawahan, orang yang tua kepada anak kecil, dan beberapa keadaan yang lain lagi. Kata saudara pada (22) menunjukkan jarak yang renggang atas suasana formal dan bisnis. Kata bapak pada (23) menunjukkan bahwa yang berbicara lebih muda dari yang diajak bicara, atau kalimat bawahan terhadap atasan, murid terhadap guru.

Dalam memperoleh bahasanya, anak juga harus menguasai toto kromo bahasa seperti ini. Hal ini menjadi lebih penting lagi pada masyarakat yang sangat peka terhadap sopan santun bahasa. Orang Jawa, Sunda, atau Bali, misalnya tidak akan dapat menyatakan maksud kalimat (21-23) dalam bahasa mereka masingmasing tanpa mempertimbangkan siapa yang diajak bicara karena bukan hanya kamu, saudara, dan bapak yang akan berubah tetapi juga kata-kata lain.

Dalam bahasa Indonesia, pronomina orang kedua mempunyai banyak bentuk: kamu, engkau, saudara, anda, bapak, ibu, dsb. Pemakaian pronominal yang mana diatur oleh aturan sosial yang tidak sederhana. Sebaliknya, pronomina Inggris you dapat dipakai untuk siapa dan kapan pun juga. Inilah pula sebabnya pada usia 2 tahun 3 bulan hingga 2 tahun 6 bulan anak Inggris telah dapat menguasai pronomina you, sedangkan Echa sampai umur 5 tahun masih kadang-kadang keliru dalam memakai kata kamu.

Berkaitan dengan pragmatik, Nino dan Snow dalam Dardjowidjojo menyarankan agar orang dewasa, para orang tua, guru, dapat mengamati (a) pemerolehan niat komunikatif (communicative intents) dan pengembangan ungkapan bahasanya, (b) pengembangan kemampuan untuk bercakap-cakap dengan segala urutannya, dan (c) pengembangan piranti untuk membentuk wacana yang kohesif. ${ }^{2} \mathrm{Hal}$ ini dikarenakan pragmatik merupakan bagian dari perilaku berbahasa maka penelitian mengenai pemerolehan bahasa, sehingga

2 Ibid., h. 266. 
perlu pula diamati bagaimana anak mengembangkan kemampuan pragmatiknya.

\section{KESIMPULAN}

Pemerolehan bahasa pertama erat sekali kaitannya dengan perkembangan sosial anak dan karenanya juga erat hubungannya dengan pembentukan identitas sosial. Mempelajari bahasa pertama merupakan salah satu perkembangan menyeluruh anak menjadi anggota penuh suatu masyarakat.

Pada umumnya anak memperoleh kecakapan berbahasa melalui bunyi-bunyi bahasa yang ia dengar di sekelilingnya tanpa disengaja atau diperintah. Kecakapan berbahasa berkembang secara terus menerus sesuai dengan perkembangan intelegensi dan latar belakang sosial-budaya yang membentuknya.

Memahami ujaran orang lain merupakan unsur pertama yang harus dikuasai manusia dalam berbahasa. Begitu pula manusia hanya memproduksi ujaran apabila dia mengetahui aturan-aturan yang harus diikuti yang diperoleh sejak kecil. Pemerolehan bahasa pada umur dewasa berbeda daripada pemerolehan sejak anak masih kecil berkaitan erat dengan struktur serta organisasi otak manusia.

\section{DAFTAR PUSTAKA}

Brown, Douglas H. (2000). Principles of Language Learning and Teaching. New York: Addison Wesly Longman.

Chomsky, N. (2006). Language and mind. Cambridge University Press.

Dardjowidjojo, Soenjono.

Psikolinguistik (Pengantar Pemahaman Bahasa Manusia). Jakarta: Unika Atma Jaya.

Dardjowidjojo, Soenjono. (2000) Kisah Pemerolehan Bahasa Anak (Echa). Jakarta: Unika Atma Jaya.

Field, John. (2003). Psycholinguistics: a resource book for students. New York: Routledge.
Gleason dan Ratner. (1998) Psycolinguistics (second edition). United Stated: Harcourt Brace College Publishers,

Harmer, Jeremy. (2001). The Practice of English Language Teaching. Harlow Essex: Pearson Education Limited .

Jacobson, Roman. (1971). Studies on Child Language and Aphasia. The Hague: Mouton Publishers.

Mukalel, Joseph C. (2003). Psychology of Language Learning. New Delhi Discovering Publishing House. 